\title{
ОБУЧЕНИЕ ЯЗЫКАМ В УСЛОВИЯХ ЯЗЫКОВОГО РАЗНООБРАЗИЯ: АНАЛИЗ ЕВРОПЕЙСКОГО ОПЫТА
}

В статье рассматривается проблема язьпков, имеюиих разньй статус и используемьх для коммуникачии в Европейском союзе. Как показылает проведенный нами анализ теоретпческих источников, статус языка имеет непосредственное влияне на его вовлеченность в образовательный прочесс. Кроме того, язькковое разнообразие как принип ЕС требует продвиюения приниипа многоязылия, предполаганомего формирование способности использовать несколько языков в практике общения. Поомрение изучения иностранньх языкков становится ведущей тенденицей поддерэнки языкового разнообразия и создания эффективньх условий для взаимодействия представителейразньххкультур вевропейском сообществе.

Ключевые слова: обучение языкам, родной язык, иностранньй язык, языковое разнообразие, многоязычие, Европейский Союз, коммуникативная компетенияя

The article deals with the problem of languages that have different status and are used for communication in the European Union. As our analysis of theoretical sources shows, the status of a language has a direct impact on its involvement in the educational process. In addition, linguistic diversity as a principle of the EU requires the promotion of the principle of multilingualism, which implies the formation of the ability to use several languages in the practice of communication. Encouraging the study of foreign languages is becoming a leading trend in maintaining linguistic diversity and creating effective conditions for interaction between representatives of different cultures in the European community.

Key Words: language teaching, mother tongue, foreign language, linguistic diversity, multilingualism, European Union, communicative competence

Как известно, языковое разнообразие является неотъемлемой частью идентичности Европы. Проблематика функционирования национальных, региональных и языков региональных и иммигрантских меньшинств касается различных вопросов, начиная от их фактического распространения и 
количества их носителей, их внутренней и общественной жизнеспособности, до процессов и мер поддержания языков. Представляется очевидным, что эти вопросы касаются не только социолингвистических и политических тенденций, но и образовательных условий.

Обратим внимание на различные статусы, которые имеют языки, используемые для коммуникации в Европейском союзе:

- национальные - языки ЕC;

- коренные языки или языки региональных меньшинств;

- нетерриториальные языки или языки иммигрантский меньшинств [Yağmur 2011].

Сложности, вызванные языковым разнообразием, касаются языков с различным статусом. Вместе с тем, политика в области изучения языков направлена на разные языки вне зависимости от их статуса, включая в том числе и языки иммигрантских меньшинств. Хотя также следует отметить, что наблюдается общая тенденция разного уровня вовлеченности языков в образовательный процесс в зависимости от их статуса. Языки меньшинств, как правило, не входят в основное образование, хотя имеются некоторые примеры европейских стран, в которых языки национальных меньшинств изучаются. Так, в Нидерландах школьники изучают предмет «Турецкий язык», который представлен в школьной программе не как родной язык, а как один из живых (используемых в мире) языков [Yağmur 2011]. Кроме того, основная проблема, касающаяся языков, имеющих разный статус - это их разные функции для коммуникации, например, язык общения дома и язык социума, который также рассматривается как язык, на котором ведется обучение.

Реализация принципа языкового разнообразия предполагает изучение не менее двух европейских языков, которые в данном случае приобретают статус иностранный для учащихся, осваивающих их. Следует уточнить, что рассматриваемый подход определяется как основополагающий аспект образовательной политики в области изучения языков, что требует систематичной организации учебного процесса и включение языковой практики на неродных языках уже на начальном уровне образования. Кроме того, для поддержания коммуникативно-достаточного уровня владения иностранными языками в программы школы на более старшем этапе включено преподавание отдельных 
предметов на иностранных языках. Таким образом, многоязычие, само по себе, становится образовательным ресурсом и, как отмечает М. Байрам, изучение иностранных языков получает развитие благодаря тандему с инициативами, предпринимаемыми региональными блоками и отдельными странами для содействия изучению нескольких языков, особенно в среднем образовании [Byram 2018].

Практика изучения нескольких иностранных языков в Европе определяется специальными мерами, направленными на поддержку языкового образования и обеспечение эффективного освоения иноязычной коммуникативной компетенции, что достигается посредством следующих мер:

- опору на специальные исследования качества языкового обучения и продвижение системы оценки уровней владения иностранными языками;

- внедрение системы стандартов Европейского качества языкового образования в школах на основе определения тех учебных заведений, которые соответствуют требованиям обучения первому и второму иностранным языкам;

- расширение обменов и связей между школами в области изучения языков;

- поддержка самостоятельного изучения языков учащимися;

- расширение обмена опытом преподавания иностранных языков и обмена учебно-методическими материалами между преподавателями и учебными заведениями;

- развитие мер поддержки раннего обучения иностранным языкам [Смокотин 2010].

В данном контексте особый интерес представляют инициативы, касающиеся не только учащихся, но и учителей в достижении целей обучения многоязычию. Р. Калафато указывает на растущее значение формирования многоязычных граждан в Европе, что достигается не только посредством разработки и внедрения эффективных учебных программ, нацеленных на успешные результаты обучения иностранным языкам учащихся, но и посредством подготовки учителей иностранных языков, которые владеют несколькими иностранными языками и тем самым мотивируют учащихся к многоязычию [Calafato 2020]. Действительно, вдохновить учащихся на изучение нескольких 
иностранных языков, продемонстрировать возможность достижения коммуникативно-достаточного уровня владения ими может учитель, который сам владеет несколькими языками и который выступает в качестве примера для подражания. Исследователи отмечают, что существуют факторы, которые отрицательно влияют на распространение многоязычия среди учителей:

- программы поготовки учителей, продвигающие одноязычный подход к обучению языкам [Ellis 2016];

- восприятие иностранных языков как имеющих меньшую ценность по сравнению с национальным языком [Bourdieu 1990].

Рассматривая тенденции, которые связаны с обучением языкам в условиях языкового разнообразия в Европе, мы считаем важным отметить исследования взаимодействия родного и неродных языков на когнитивном и социальном уровнях [Commins 2011]. Если когнитивный уровень предполагает изучение индивидуального характера взаимодействия, переключения с одного языка на другой, преферентного обращения к тому или иному языку в конкретных условиях общения, трудностей освоения языков и языковую интерференцию, то социальный уровень исследований ориентирован на выработку специальных мер функционирования языков в обществе. Тем не менее, ученые подчеркивают, что взаимодействие языков функционирует как дополнительное средство для развития многоязычия и умений переключаться с языка на язык только при условии создания эффективной образовательной среды, «которая позволяет учащимся развивать языки, которыми они владеют, наиболее эффективными и полезными способами, признавая, что учащиеся в любом классе имеют разные уровни сформированности коммуникативной компетенции, что требует использования специальных приемов организации речевой деятельности на языках» [Alisaari 2019]. Определяющим при взаимодействии языков является родной язык учащихся, который необходимо учитывать при организации обучения иностранным языкам: «существующие знания, которыми учащиеся, осваивающих иностранные языки, овладевают, прежде всего, закодированы на их родных языках» [Cummins 2005] и, таким образом, обучение должно опираться на 
знание родного языка, который становится первым языковым опытом обучающихся.

В заключение, изучение языков в условиях языкового разнообразия направлено на формирование способностей к многоязычию, включающих освоение нескольких иностранных языков и формирование многоязычной личности. Практика преподавания языков в Европе свидетельствует о широких возможностях достижения искусственного многоязычия при условии специально организованного обучения языкам. Поддержка многоязычю осуществляется как на государственном, так и на индивидуальном уровне.

\section{ЛИТЕРАТУРА}

1. Смокотин B.M. Основные инструменты политики многоязычия и поликультурности в Европе: общие европейские языковые компетенции и языковой портфель // Вестник Томскогогосударственногоуниверситета. 2010.№ 337.-C. 72-77.

2. Alisaari J., Heikkola L.M., Commins N., Acquah E.O. Monolingual ideologies confronting multilingual realities. Finnish teachers' beliefs about linguistic diversity // Teaching and Teacher Education. 2019. Issue 80.-Pp. 48-58.

3. Bourdieu P. Was heißt sprechen? Zur €Okonomie des sprachlichen Tausches. Wien: Braumiller, 1990.-183 S.

4. Byram M. Language education in and for a multilingual Europe. // Foreign Language Education in Multilingual Classrooms. Amsterdam: John Benjamins Publishing Company, 2018. -Pp. 33-56.

5. Calafato R. Evaluating teacher multilingualism across contexts and multiple languages: validation and insights // Heliyon. 2020. [Электронный ресурc]. URL: https://doi.org/10.1016/j.heliyon .2020.e04471 (дата обращения: 17.04.2021).

6. Commins N. L. Meaning is everything: Comprehension work with second language learners // Comprehension going forward: Where we are and what's next? Portsmouth NH: Heinemann, 2011.-Pp. 192-214.

7. Cummins J., Bismila V., Chow P., CohenP., Giampapa F., Leoni L. Affirming identity in multilingual classrooms //Educational Leadership. 2005. Issue63(1).-Pp. 38-43.

8. Ellis E.M. The Plurilingual TESOL Teacher: The Hidden Languaged Lives of TESOL Teachers and Why They Matter. Boston, MA: De Guyter Mouton, 2016. [лектронный ресурc]. URL: DOI:10.1515/9781614513421 (дата обращения: 16.04.2021).

9. Yağmur K. Extra G. Urban multilingualism in Europe: Educational responses to increasing diversity // Journal of Pragmatics. 2011. Issue 43.-Pp. 1185-1195. 